\title{
Psychiatric Disorders, Delirium and Mortality in Patients Referred for Consultation in a Burn Center: A Four-Year Retrospective Study
}

\author{
Yanık Merkezinde Konsültasyon Istenen Hastalardaki Psikiyatrik Bozukluklar, \\ Deliryum ve Mortalite: Dört Yıllık Bir Retrospektif Çalışma \\ Esin Erdoğan $\odot$, Dursun Hakan Delibaş $\odot$ \\ University of Health Sciences, Izmir Bozyaka Training and Research Hospital, Clinic of Psychiatry, Turkey
}

Received: 29 February 2020 / Accepted: 02 March 2020 / Publication date: 26 March 2020

Cite as: Erdoğan E, Delibaş DH. Psychiatric disorders, delirium and mortality in patients referred for consultation in a burn center: A four-year retrospective study. Med J Bakirkoy 2020;16(1):62-70.

\section{ABSTRACT}

Objective: The aim of this study was to examine psychiatric disorders after burn trauma and burn-related features in adults. Method: The records of the cases who were hospitalized in the burn center between January 2015 and January 2019 and for whom psychiatric consultation was requested were retrospectively reviewed. Sociodemographic characteristics, burn-related features, psychiatric diagnoses, and treatments of the patients were examined.

Results: The mean rate of psychiatric consultations requested in a burn center within a four-year period was $34.05 \%$ and 49 $(28.5 \%)$ of these consulted cases had a work-related accident. Mean hospitalization time was $37.2 \pm 24$ days and the most common burn type was a fire/flame injury. In the majority of the study sample (63.4\%) the total body surface area burnt was more than $20 \%$. Nineteen (11\%) cases had a history of psychiatric disorder. The most common psychiatric diagnosis before burn injury was alcohol-drug addiction ( $n=14,73.7 \%)$. The most common diagnosis after psychiatric consultation was adjustment disorder (31.9\%). Among psychotropic drugs the initial treatment was started most frequently treatment with benzodiazepines (30.8\%) and antipsychotics (58.1\%). In 33 deceased cases, the most common psychiatric diagnosis was delirium with a rate of $42.4 \%$.

Conclusion: The incidence of psychiatric disorders before and after burn injury was found to be high in the individuals. Conditions with a high risk of morbidity and mortality, such as delirium, should be diagnosed and treated priorly. Due to the early and long-term effects of burn trauma, a multidisciplinary approach should be developed and psychiatrists should be included in the management of treatment.

Keywords: burn, psychiatric disorder, delirium, mortality

ÖZ

Amaç: Erişkinlerde yanık travması sonrasında ortaya çıkan psikiyatrik bozuklukların ve yanıkla ilişkili özelliklerin incelenmesi amaçlanmıștır.

Yöntem: Ocak 2015-Ocak 2019 yılları arasında yanık merkezinde yatarak tedavi gören ve psikiyatri konsültasyonu istenen olguların kayıtları geriye dönük olarak taranmıştır. Olguların sosyodemografik özellikleri, yanıkla ilişkili özellikleri, psikiyatrik tanıları ve tedavileri incelenmiștir.

Bulgular: Yanık merkezinde 4 yıllık süre içinde psikiyatri konsültasyonu istenme oranı \%34.05'ti, danışılan olguların 49'u (\%28.5) iş kazası geçirmişti. Ortalama yatış süreleri $37.2 \pm 24$ gün olup, en sık yanık şekli yangın/alev yaralanmasıydı. Örneklemin büyük çoğunluğunda (\%63.4) toplam vücut yüzey alanı \%20'den fazlaydı. 19 (\%11) olgunun geçmişte psikiyatrik hastalığı mevcuttu. Yanık öncesi en sık görülen psikiyatrik tanı alkol-madde bağımlılığıydı.(n=14, \%73.7). Psikiyatrik konsültasyon sonucu en yüksek konulan tanı ise uyum bozukluğuydu (\%31.9). Psikotrop ilaçlar içinde benzodiyazepin (\%30.8) ve antipsikotik (\%58.1) başlanma oranı yüksekti. Vefat eden 33 olguda en sık görülen psikiyatrik tanı \%42.4 oranıyla deliryumdu.

Sonuç: Yanık geçiren bireylerde yanık öncesinde ve sonrasında psikiyatrik hastalıkların görülme oranı yüksektir. Özellikle deliryum gibi morbidite ve mortalite riski olan durumlar öncelikle tedavi edilmelidir. Yanık travmasının erken ve uzun dönemdeki ruhsal etkileri nedeniyle multidisipliner yaklaşım sağlanarak tedavi yönetimine psikiyatristlerin dahil edilmesi önemlidir.

Anahtar kelimeler: yanık, psikiyatrik bozukluk, deliryum, mortalite 


\section{INTRODUCTION}

Severe physical injuries and burns constitute approximately $12 \%$ of the diseases in the world (1). Whatever the reasons are, injuries are a major burden on the healthcare system which is responsible for the care and support of victims. Researchers believe that $98 \%$ of these cases are preventable. Although the age-adjusted injury mortality rate has been reduced by $21 \%$ between 1980 and 1997, the intentional and unintentional injuries are still the leading cause of death for children, adolescents and young adults ${ }^{(1)}$. Physical and psychological rehabilitation of these patients have become more important as a result of the increase in survival rates due to the developments in medicine ${ }^{(2)}$.

From an etiological point of view, psychiatric disorders and burns are interrelated. After a severe trauma, such as burn injury, especially burns which cause distinct physical distortion of the face, can lead to psychiatric diseases, and mental illnesses eventually to a predisposition to burn injuries ${ }^{(1,3)}$. From a psychiatric point of view, people with substance use disorders are at higher risk of injury, including burns (4). Similarly, suicidal patients with a mental disorder may also deliberately burn themselves ${ }^{(5,6)}$. The prevalence of depression is higher among individuals who are traumatically injured and have a medical illness compared to the general population ${ }^{(7,8)}$. The presence of a pre-existing psychiatric disorder in burn patients is associated with worse outcomes in the treatment of burns and is an important predictor of morbidity. In addition, the development of psychiatric disorder after burn injury is reported to be a factor negatively affecting the quality of life ${ }^{(9-11)}$. In the burn injury process and during the treatment, mental illnesses can be seen in patients due to severe pain, prolongation of treatment process, being confined to bed, and changes in body image ${ }^{(12)}$. In this respect, it is important that patients are also evaluated from a psychiatric point of view after the initial emergency intervention in the burn unit, and psychiatrists should be included in the burn treatment team ${ }^{(13)}$.

Delirium is one of the most common diagnoses in patients referred to psychiatric services from different wards ${ }^{(14)}$. Prevalence of delirium among inpati- ents is found to range from 10 to $30 \%{ }^{(15)}$. Delirium is characterized by an acute decline in the level of consciousness and cognition with particular impairment in attention. Other associated features include abnormal psychomotor activity, sleep cycle impairment and psychiatric symptoms such as abnormalities of mood, perception and behaviour. It develops over a short period of time and fluctuates during the course of the day ${ }^{(16)}$. Studies on this field frequently state that delirium has significant effects on medical morbidity, hospitalization time, and postdischarge course ${ }^{(17,18)}$. Delirium is therefore a clinical diagnosis that requires emergent medical care and treatment in burn patients and it may be fatal if not treated (19).

Studies conducted in Turkey examining burns and mental disorders were reviewed, and a study analyzing family characteristics of children and adolescents with corrosive burns and another study evaluating burn related psychiatric disorders in children were identified ${ }^{(20,21)}$. There was only one study examining psychiatric disorders in the early period in an adult population ${ }^{(22)}$. Therefore, our study will contribute to the literature in this field. The aim of this study is to examine the distribution of psychiatric diagnoses, clinical characteristics and treatments in psychiatric consultations requested by the burn center.

\section{MATERIAL and METHODS}

The burn center in our hospital consists of 12 beds -eight for service and four for intensive care-, an operating room, two dressing rooms, hydrotherapy halls, one hyperbaric oxygen therapy device and one polyclinic. It is a tertiary treatment center providing healthcare to an important population in the Aegean region, which accepts moderate and severe burn patients and patients with additional trauma or comorbidities over 18 years of age. This center provides healthcare services to 250 inpatients per year on average. A total of 172 cases that were hospitalized in the burn center between January 2015 and January 2019 and for whom psychiatric consultation was requested were retrospectively evaluated. According to the good clinical practice guidelines written approval was obtained from the hospital comittee in order to examine the medical records of 
the cases retrospectively. Data such as age, gender, education, marital status, occupation, cause, and location of the burnt area on body, whether it is an work-related accident, percentage of total body surface area (TBSA\%) burnt, psychiatric history and diagnosis, alcohol-substance abuse, number of consultations requested from psychiatry, the time between hospitalization and request for psychiatric consultation length of hospital stay, and the psychotropic drugs used were examined.

Statistical Analysis: SPSS 22 statistical package program was used in all analyses. In addition to descriptive statistics (median and percentage distributions), Mann Whitney-U test was used and categorical variables were compared using chi-square test. $\mathrm{P}<0.05$ was considered statistically significant.

\section{RESULTS}

In 505 cases hospitalized in the burn center during the four-year period, psychiatric consultations were requested for 172 (34.05\%) cases. Of these cases, 39 (22.7\%) were female and 133 (77.3\%) were male. The median age of the patients was 37 (25-52) years and the majority were married ( $n=94,54.7 \%$ ). The median duration of education was 5 (5-11) years, and 91 patients $(52.9 \%)$ were unemployed. Fortynine (28.5\%) patients had an occupational accident, and the majority of these cases were male workers $(p=0.014)$. Overall and gender-based sociodemographic characteristics of the cases are given in Table 1.
The median length of hospitalization in the intensive care unit was 6.5 (4-11) days and total length of hospitalization was 15.5 (3-40) days. The most common burn pattern was fire-flame injury $(n=120,69.8 \%)$. The most common areas of burn injury were the areas apart from the head and neck, hands and the genital region $(n=87,50.6 \%)$. Nineteen $(11 \%)$ patients had a history of psychiatric disorder, including alcohol-drug addicts ( $n=14: 73.7 \%)$, those with bipolar mood disorder $(n=2: 10.5 \%)$, psychotic disorder $(n=1)$, delirium $(n=1)$, and adjustment disorder $(n=1$ : $5.3 \%)$. In the whole sample, $10(5.8 \%)$ cases were hospitalized due to self inflicted burns. Of the 10 patients who burned themselves, 2 had dependence, 1 had bipolar mood disorder, and 1 had psychotic disorder before burn trauma. Psychiatric consultation was requested for 94 patients (54.6\%), during the first week of hospitalization and the most common psychiatric diagnosis after evaluation of all cases was adjustment disorder ( $n=54,31.4 \%)$. As a result of the consultation, antidepressants were used in 78 $(45.3 \%)$, benzodiazepines in $53(30.81 \%)$, antipsychotics in 100 (58.1\%), and multiple psychotropic agents in 49 (28.5\%) cases. The details of the psychiatric consultation requested for burn patients are given in Table 2 and the distribution of psychiatric diagnoses received by the patients is given in Table 3 .

Thirty-three (19.2\%) patients died due to cardiac arrest, sepsis, multiple organ failure and adult respiratory distress syndrome during burn treatment. The most common psychiatric diagnosis among these

Table 1. Sociodemographic characteristics of cases who were evaluated by the psychiatrist.

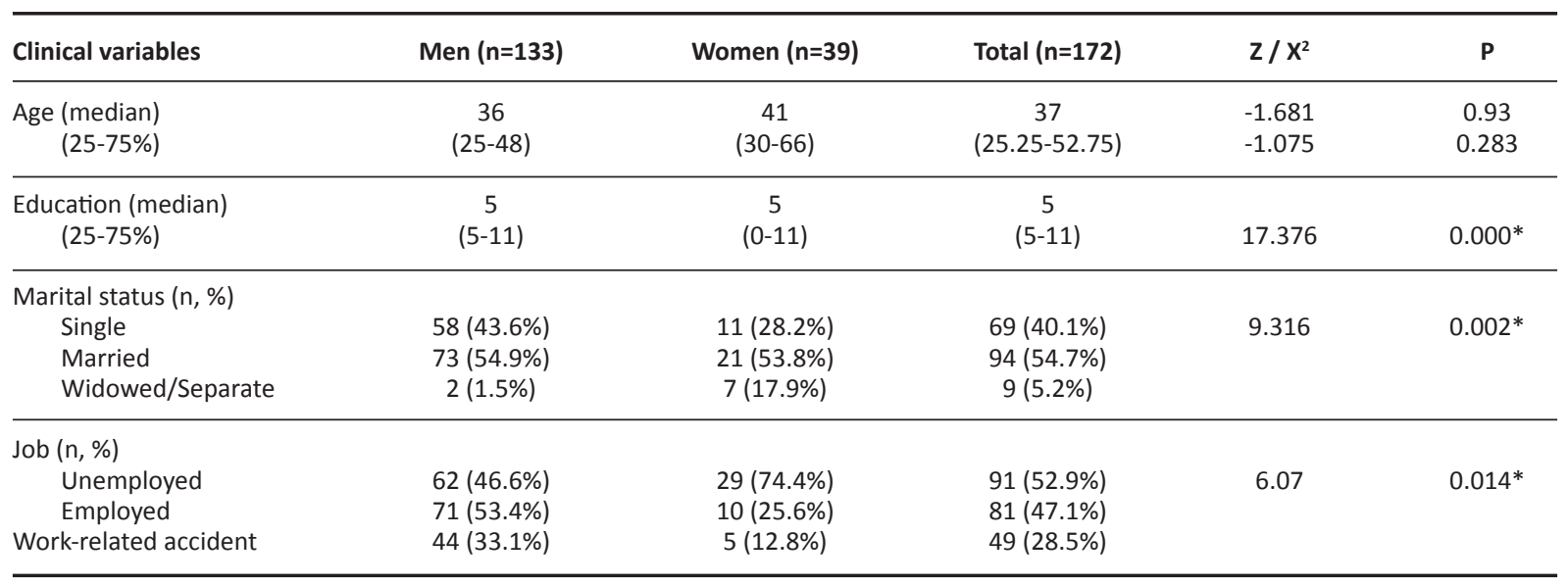

${ }^{*} p<0.05$ was considered as statistically significant 
E. Erdoğan and D. H. Delibaş, Psychiatric Disorders, Delirium and Mortality in Patients Referred for Consultation in a Burn Center: A Four-Year Retrospective Study

Table 2. Clinical chracteristics of the patients who were evaluated by the psychiatrist.

\begin{tabular}{|c|c|c|c|c|c|}
\hline Clinical variables & Men (n=133) & Women $(n=39)$ & Total $(n=172)$ & $z / X^{2}$ & $\mathbf{P}$ \\
\hline $\begin{array}{l}\text { Duration of intensive care stay (median) } \\
\quad(25-75 \%)\end{array}$ & $\begin{array}{c}6 \\
(4-11)\end{array}$ & $\begin{array}{c}7 \\
(2-11)\end{array}$ & $\begin{array}{c}6.5 \\
(4-11)\end{array}$ & $\begin{array}{l}-0.227 \\
-0.634\end{array}$ & $\begin{array}{l}0.634 \\
0.526\end{array}$ \\
\hline $\begin{array}{l}\text { Duration of total hospitalization (median) } \\
\qquad(25-75 \%)\end{array}$ & $\begin{array}{c}17 \\
(3-41)\end{array}$ & $\begin{array}{c}14 \\
(1-39)\end{array}$ & $\begin{array}{c}15.5 \\
(3-40)\end{array}$ & 15.31 & $0.000 *$ \\
\hline $\begin{array}{l}\text { Type of burn }(n, \%) \\
\text { Fire/flame } \\
\text { Scald } \\
\text { Other (chemical-electrical) }\end{array}$ & $\begin{array}{c}90(67.7 \%) \\
8(6 \%) \\
33(24.8 \%)\end{array}$ & $\begin{array}{c}30(76.9 \%) \\
8(20.5 \%) \\
1(2.6 \%)\end{array}$ & $\begin{array}{c}120(69.8 \%) \\
16(9.3 \%) \\
36(20.9 \%)\end{array}$ & 4.257 & 0.235 \\
\hline $\begin{array}{l}\text { Site of injury }(n, \%) \\
\text { Head } \\
\text { Hand } \\
\text { Genital area } \\
\text { Other }\end{array}$ & $\begin{array}{c}32(30.9 \%) \\
21(15.8 \%) \\
12(9 \%) \\
68(51.1 \%)\end{array}$ & $\begin{array}{c}8(20.5 \%) \\
4(10.3 \%) \\
8(20.5 \%) \\
19(48.7 \%)\end{array}$ & $\begin{array}{l}40(23.3 \%) \\
25(14.5 \%) \\
20(11.6 \%) \\
87(50.6 \%)\end{array}$ & 2.646 & 0.084 \\
\hline $\begin{array}{l}\text { Mortality (n, \%) } \\
\text { TBSA }(n, \%) \\
\quad 0-10 \\
10-20 \\
>20\end{array}$ & $\begin{array}{c}22(16.5 \%) \\
12(9 \%) \\
36(38.7 \%) \\
85(63.9 \%)\end{array}$ & $\begin{array}{c}11(28.2 \%) \\
1(2.6 \%) \\
14(35.9 \%) \\
24(61.5 \%)\end{array}$ & $\begin{array}{c}33(19.2 \%) \\
13(7.6 \%) \\
50(29.1 \%) \\
109(63.4 \%)\end{array}$ & 2.5 & 0.287 \\
\hline
\end{tabular}

TBSA: Total body surface area, ${ }^{*} p<0.05$ was considered as statistically significant

Table 3. Distribution of psychiatric diagnoses in patients who were evaluated by the psychiatrist.

\begin{tabular}{|c|c|c|c|c|c|}
\hline $\begin{array}{l}\text { Psychiatric diagnosis } \\
(n, \%)\end{array}$ & Men $(n=133)$ & Women (n=39) & Total $(n=172)$ & $X^{2}$ & $\mathbf{P}$ \\
\hline Adjustment disorder & $44(33.1 \%)$ & $10(25.6 \%)$ & $54(31.4 \%)$ & & \\
\hline Anxiety disorders & 25 (18.8\%) & $8(20.5 \%)$ & $33(19.2 \%)$ & & \\
\hline Depression & $18(13.5 \%)$ & $11(28.2 \%)$ & 29 (\%16.9) & 7.105 & 0.130 \\
\hline Delirium & $20(15 \%)$ & $7(17.9 \%)$ & 27 (15.7\%) & & \\
\hline Other Diagnosis & $26(19.6 \%)$ & $3(7.7 \%)$ & $29(16.9 \%)$ & & \\
\hline Substance use disorder & $16(12 \%)$ & - & $16(9.3 \%)$ & & \\
\hline Acute stress disorder & $8(6 \%)$ & $2(5.1 \%)$ & $10(5.8 \%)$ & & \\
\hline Bipolar disorder & $1(0.8 \%)$ & $1(2.6 \%)$ & $2(1.2 \%)$ & & \\
\hline Psychotic disorder & $1(0.8 \%)$ & - & $1(0.6 \%)$ & & \\
\hline
\end{tabular}

$p<0.05$ was considered as statistically significant

Table 4. Distribution of psychiatric diagnoses in patients who died in burn center.

\begin{tabular}{lccc}
\hline $\begin{array}{l}\text { Psychiatric diagnosis } \\
(\mathbf{n}, \%)\end{array}$ & $\begin{array}{c}\text { Men } \\
(\mathbf{n = 2 2 )}\end{array}$ & $\begin{array}{c}\text { Women } \\
(\mathbf{n = 1 1 )}\end{array}$ & $\begin{array}{c}\text { Total } \\
(\mathbf{n}=\mathbf{3 3})\end{array}$ \\
\hline Adjustment disorder & $5(22.7 \%)$ & $3(27.3 \%)$ & $8(24.2 \%)$ \\
Anxiety disorders & $3(13.6 \%)$ & - & $3(9.1 \%)$ \\
Depression & - & $2(18.2 \%)$ & $2(6.1 \%)$ \\
Delirium & $10(45.5 \%)$ & $4(36.4 \%)$ & $14(42.4 \%)$ \\
Other Diagnosis & $4(18.2 \%)$ & $2(18.2 \%)$ & $6(\% 18.2)$ \\
$\quad$ Substance use disorder & $4(8.21 \%)$ & - & $4(12.1 \%)$ \\
$\quad \begin{array}{l}\text { Acute stress disorders } \\
\text { Bipolar disorders }\end{array}$ & - & $1(9.1 \%)$ & $1(3 \%)$ \\
$\quad$ Psychotic disorders & - & $1(9.1 \%)$ & $1(3 \%)$ \\
& - & - & - \\
\hline
\end{tabular}

$p<0.05$ was considered as statistically significant cases was delirium ( $n=14,42.4 \%)$. Distribution of psychiatric diagnoses in these 33 cases according to gender is given in Table 4.

\section{DISCUSSION}

Burn trauma results in outcomes with negative psychological, social and physical effects in the exposed individuals in the short-, and long- term. In the present study, retrospective evaluation of the fouryear period revealed that psychiatric consultation was requested in $34 \%$ of the patients who were hospitalized at the burn center. When a study was 
evaluated in the literature, it was observed that the rate of psychiatric consultation after burn injury was reported as $19.6 \%{ }^{(23)}$. Gender and age are important risk factors for severe burn injuries associated with adverse developmental and behavioral patterns (24). In our study, the mean age of burn patients was 40.51 years and majority of the patients were male $(\mathrm{F} / \mathrm{M}$ ratio=1/3). These results are consistent with the results of other studies in the literature ${ }^{(25-27)}$. Similarly, employment status and rate of workrelated accidents were found to be significantly higher in men, consistent with other studies ${ }^{(25-28)}$. This result may be attributed to a higher proportion of males working in high risk sectors in Turkey, as is the case in rapidly industrializing countries.

In the present study, the majority of cases requiring psychiatric consultation were hospitalized in the intensive care unit. Mean length of hospitalization in the burn center was $37.2 \pm 24.3$ days. When the literature is reviewed, it can be seen that the mean length of hospitalization varies between centers. Ter Smitten et al. (2011) reported mean length of hospitalization as $27 \pm 30$ days ${ }^{(27)}$, whereas Logsetty et al. (2016) as $15.1 \pm 21.8$ days ${ }^{(9)}$. The length of hospitalization in burn centers can be affected by various parameters such as severity of burn, presence of intensive care unit, additional medical diseases, complications, and premorbid psychiatric diagnosis (29). In the present study, the most common cause of burn was fire/flame with a ratio of $76.9 \%$. Second most common cause was scalding in women and other (electric/chemical) burns in men, and there was a statistically significant difference between the genders. Similar to our study, there was a difference between the genders in the literature ${ }^{(26,28,30)}$. When three studies conducted in Turkey were examined, it was seen that scalding burns $(60.7 \%, 69 \%, 47.7 \%)$ were reported as the most common causes of burns (31-33). However, there is no gender comparison in these studies, and we believe that the absence of a burn intensive care unit in those centers and the referral of severe/complicated cases to other hospitals may have affected the causes of burns. In an other retrospective study, Yücel and Kılavuz reported that among moderately severe burns the scalding burns (52.6\%) and among severe burns flame burns (54.4\%) were the most common causes of burn injuries ${ }^{(30)}$.
When location of burn was examined in our study, it was observed that the body regions other than the head, hands and the genital region were affected the most. The severity of the burn is an important risk factor in the development of psychiatric disorder. In one study, at least one mental disorder was found to develop in one third of minor burns (TBSA $<5 \%)$, two thirds of moderate burns (TBSAP $=5-20 \%$ ), and almost all of severe burns (TBSA $>20 \%{ }^{(23)}$. In our study, the majority of the cases requiring psychiatric consultation $(n=109,63.4 \%$ ) had a TBSA of over $20 \%$. This finding is consistent with the results of another study examining 10 years of data in Turkey ${ }^{(28)}$. In the literature, Özçetin et al. (2012) reported that TBSA was $6-10 \%$ in the majority of cases ${ }^{(32)}$, and Sikar et al. (2018) reported that TBSA was $6-15 \%{ }^{(31)}$ In the presence of severe burns, as encountered in the intensive care units, psychiatric support is especially important for patients who develop complications (26). The higher rate of hospitalization in the intensive care unit in our study supports the need for psychiatric evaluation. Another important issue is that the mean length of hospitalization and the duration of transition to independent life are higher in patients with pre-burn psychiatric disorders compared to others (34). In individuals, the presence of mental illness before burn may sometimes be the cause of the burn itself (self-harm), and reasons such as the low treatment motivation caused by depression, the lack of proper wound care due to the difficulty in assessing reality can make the treatment and healing process difficult ${ }^{(35,36)}$. In some studies, it has been reported that a significant number of patients admitted to burn centers have pre-burn Axis I and Axis II psychiatric disorders, and some personality traits such as impulsivity predisposes to burn injury ${ }^{(26,37)}$. It was also found that this patient group stayed longer in the hospital and required greater number of surgical procedures, thus creating difficulties for various disciplines in the treatment and rehabilitation process ${ }^{(35)}$. In our study, 19 patients $(11 \%)$ had a psychiatric diagnosis before burn incident. When the distribution of the diagnoses in this group was examined, it was found that $74 \%$ of them had alcohol-drug dependence and $11 \%$ of them bipolar mood disorder. Palmu et al. (2010) evaluated 107 acute burn patients and reported the rate of previous psychiatric treatment as $29 \%{ }^{(26)}$. Logsetty et al. (2016) found that the rate of any psychiatric disorder in burn vic- 
E. Erdoğan and D. H. Delibaş, Psychiatric Disorders, Delirium and Mortality in Patients Referred for Consultation in a Burn Center: A Four-Year Retrospective Study

tims in the last 2 years before burn injury was $25.5 \%$ (9). In our study, it was determined that $10(5.8 \%)$ cases experienced burn trauma due to self-harm/ suicide. In this group, two cases had alcohol and drug dependence, one case had bipolar mood disorder, and the other one had psychotic disorder. In our study, it is noteworthy that most of the individuals who suffered burns due to self-harm did not receive psychiatric support before the burn. Therefore, it can be thought that this group demonstrates impulsive decision and behavioral characteristics.

Burn team requested psychiatric consultations within the first week in $54.6 \%$ of the patients and the most frequent diagnosis based on psychiatric evaluation was adjustment disorder (31.4\%). In a similar study, the rate of adjustment disorder was found to be $61.5 \%{ }^{(38)}$. Adjustment disorder is among the most common psychiatric diagnoses in patients hospitalized for medical and surgical reasons, and its prevalence in patients receiving palliative care in hematology and oncology clinics was reported to be $15.4 \%$ and $19.4 \%$ respectively ${ }^{(39,40)}$. In the case of emotional and behavioral symptoms that do not meet the criteria of acute stress disorder after acute trauma, psychiatrists may turn to the diagnosis of adjustment disorder ${ }^{(41,42)}$. This may have also increased the rate of this diagnosis in our sample. When the distribution of other psychiatric diagnoses was examined in our study, anxiety disorder was found in $19.2 \%$, major depression in $16.9 \%$ and delirium in $15.7 \%$ of the cases. In a study investigating the distribution of psychiatric diagnoses in inpatients in the overall hospital sample in Turkey, the prevalence of depressive disorders, delirium, schizophrenia-psychosis, anxiety disorder, trauma and related disorders, and alcoholsubstance use disorder were reported to be $19.5 \%$, $18.2 \%, 7.4 \%, 6.1 \%, 5.6 \%$, and $4.3 \%$, respectively ${ }^{(43)}$. The prevalence of mental disorders in the overall hospital sample is affected by variables such as the duration of the additional medical disease(s), the nature of the trauma, characteristics of previous psychiatric disorder, the knowledge of the treatment team about the psychiatric disorder, the presence of psychosocial support systems and the loss of functioning in the individual ${ }^{(24,42,44)}$. Palmu et al. (2010) reported substance-related disorders (46.7\%) as the most common lifetime disorder among burn patients ${ }^{(26)}$. This ratio is quite high compared to our results. This may be due to the fact that the prevalence of substance abuse in Turkey is lower compared to other developed countries ${ }^{(45)}$. In the same study, the diagnosis of lifetime psychotic disorder was $10.3 \%$ which was above the community average. One in four people had mood disorder throughout their life, and $5.6 \%$ of them had depression during the month before the burn. Similar to our results, anxiety disorder was defined in $14 \%$ and acute stress disorder in $5.8 \%$ of their patients ${ }^{(26)}$. Yabanoğlu et al. (2012) reviewed the files of 1369 cases, and reported that the rate of psychiatric diagnosis within 15 days after the burn incident was $3.2 \%$, and the diagnoses were PTSD in $26.6 \%$, delirium in $24.4 \%$, anxiety disorder in $17.7 \%$, depression in $15.5 \%$ of the patients, respectively ${ }^{(22)}$. In our study, we observed that 33 patients (19\%) died during the four-year period and the majority of this group was diagnosed as delirium ( $n=14,42.4 \%)$. In another study with large sample of cases in which burn patients were examined in general, the mortality rate was found to be $7.4 \%{ }^{(30)}$. Delirium can be seen in one fifth of burn patients ${ }^{(36)}$. Previous studies have reported that delirium is a predictor of mortality in risky groups ${ }^{(46,47)}$. Delirium may lead to increased mortality and morbidity as new risk factors are added to the underlying etiology due to inadequate diagnosis of the delirium and the application of inappropriate treatments ${ }^{(48)}$. Therefore, early diagnosis and management of the treatment of delirium are important issues.

In a study examining psychiatric consultations requested at a university hospital, it was found that $35.2 \%$ of the patients were treated with antidepressants followed by antipsychotics (22.6\%), benzodiazepines (9\%) and $32 \%$ of them were followed-up without drug treatment ${ }^{(49)}$. On the other hand, Göktaş et al. (2006) recommended antidepressants to $65.4 \%$ of the patients consulted, antipsychotic to $9.8 \%$, and benzodiazepine to $3.7 \%$; and $19.4 \%$ of the patients were recommended with unmedicated follow-up ${ }^{\left({ }^{50}\right)}$. Similarly, Köroğlu et al. (2011) initiated antidepressants in $65.4 \%$, antipsychotics in $10.8 \%$, and benzodiazepines in $6.7 \%$ of their patients ${ }^{(51)}$. When the distribution of psychotropic drugs initiated in our study as a result of psychiatry consultation was examined, it was found that antidepressants were used in $45.3 \%$, benzodiazepines in $30.8 \%$, and antipsychotics in $58.1 \%$ of the patients. The rate of 
multiple psychotropic drug use was $28.5 \%$. In our study, the use of benzodiazepines and antipsychotics was higher compared to studies investigating clinics other than burn centers, which can be attributed to reasons such as severe anxiety, fear of death, disturbance in the sleep-wake cycle, and delirium risk in burn patients as reported in the literature ${ }^{(52)}$.

Studies have reported that individuals suffering from burn injuries use more health care in general before and after the incident, which increases the burden of care in health services ${ }^{(9)}$. Burn victims constitute a sensitive group for healthcare personnel due to increased risk of psychopathology and ongoing care needs. Therefore, it is important to examine the parameters for maintaining mental health in this population and to plan multidisciplinary approaches in the early and late stages of treatment.

The present study has some limitations. These include the nonuse of structured psychiatric interview scales and the retrospective methodology. When current literature is reviewed, this study is important because of the limited number of studies investigating burn data with respect to psychiatric consultations in Turkey. As a result of this study, another prospective study was planned in which the individuals hospitalized in the burn center of our hospital will be examined.

\section{CONCLUSION}

Mental disorders are more common in burn victims before and after the incident compared to the general population. Screening the symptoms of mental disorders and psychotherapeutic and pharmacological interventions in syndromic cases after acute care in hospital conditions will lead to better management of burn treatment and rehabilitation as well as psychiatric disorders. Especially syndromes with a high risk of mortality, such as delirium, should be treated promptly because of the adverse effects on the course of treatment and clinical picture and since most of these syndromes are most likely reversible. Therefore, delirium should be recognized in hospitalized burn patients, and co-operation should be made with the burn treatment team on prevention and treatment modalities. In addition, there is a need for prospective studies evaluating long-term psychiatric disorders in individuals suffering from burn trauma.

Ethics Committee Approval: SBI. Approval was obtained from the Ethics Committee of Bozyaka Training and Research Hospital (B.10.ITKH.4.35.T.A8.0.03 / 71-265, 22.05.2019).

Conflict of Interest: No conflict of interest was declared by the authors.

Funding: No funding was used for this study. Informed Consent: Informed consent was not obtained due to the retrospective design of the study.

\section{REFERENCES}

1. Peden M, McGee K, Sharma G. The injury chartbook: A graphical overview of the global burden of inuries. Geneva: World Health Organization; 2002.

2. Madianos MG, Papaghelis M, loannovich J, Dafni R. Psychiatric disorders in burn patients: A follow-up study. Psychother Psychosom. 2001;70:30-7. https://doi.org/10.1159/000056222

3. Delibaş DH. Yanıkta psikiyatri. İzmir Eğitim ve Araştırma Hastanesi Tıp Dergisi. 2015;22(Ek 1):59-62.

4. Haum A, Perbix W, Hack HJ, Stark GB, Spilker G, Doehn M. Alcohol and drug abuse in burn injuries. Burns. 1995;21(3):194-9.

https://doi.org/10.1016/0305-4179(95)80008-C

5. Suominen K, Henriksson M, Suokas J, Isometsa E, Ostamo A, Lonnqvist J. Mental disorders and comorbidity in attempted suicide. Acta Psychiatr Scand. 1996;94(4):234-40. https://doi.org/10.1111/j.1600-0447.1996.tb09855.x

6. Palmu R, Isometsa E, Suominen K, Vuola J, Leppavuori A, Lonnqvist J. Self-inflicted burns: An eight year retrospective study in Finland. Burns. 2004;30(5):443-7.

https://doi.org/10.1016/j.burns.2004.01.020

7. Bebbington P. The World Health Report 2001. Soc Psychiatry Psychiatr Epidemiol. 2001;36(10):473-4. https://doi.org/10.1007/s001270170010

8. Evans DL, Charney DS, Lewis L, Golden RN, Gorman JM, Krishnan KR, et al. Mood disorders in the medically ill: Scientific review and recommendations. Biol Psychiatry. 2005;58(3):175-89 https://doi.org/10.1016/j.biopsych.2005.05.001

9. Logsetty S, Shamlou A, Gawaziuk JP, March J, Doupe M, Chateau $D$, et al. Mental health outcomes of burn: A longitudinal population-based study of adults hospitalized for burns. Burns. 2016:42(4):738-44 https://doi.org/10.1016/j.burns.2016.03.006

10. Hudson A, Youha AH, Samargandi OA. Pre-existing psychiatric disorder in the burn patient is associated with worse outcome. Burns. 2017;43(5):973-82 https://doi.org/10.1016/j.burns.2017.01.022

11. Palmu R, Partonen T, Suominen K, Saarni SI, Vuolaet J, Isometsa $\mathrm{E}$. Health-related quality of life 6 months after burns among hospitalized patients: Predictive importance of mental disorders and burn severity. Burns. 2015;41(4):742-8. https://doi.org/10.1016/j.burns.2014.11.006

12. Klinge K, Chamberlain DJ, Redden M, King L. Psychological adjustments made by post burn injury patients: An integrative literature review. J Adv Nurs. 2009;65(11):2274-92. https://doi.org/10.1111/j.1365-2648.2009.05138.x

13. Watkins PN1, Cook EL, May SR, Still JM. The role of the psychiatrist in the team treatment of the adult patient with burns. J 
E. Erdoğan and D. H. Delibaş, Psychiatric Disorders, Delirium and Mortality in Patients Referred for Consultation in a Burn Center: A Four-Year Retrospective Study

Burn Care Rehabil. 1992:13(1):19-27. https://doi.org/10.1097/00004630-199201000-00006

14. Solomon S, Thilakan P, Jayakar J. Prevalence, phenomenology and etiology of delirium in medically ill patients. Int J Res Med Sci. 2016;4(3):920-5. https://doi.org/10.18203/2320-6012.ijrms20160543

15. Siddiqi N, House AO, Holmes JD. Occurrence and outcome of delirium in medical in-patients: A systematic litearture review. Age Ageing. 2006;35(4):350-64. https://doi.org/10.1093/ageing/afl005

16. Sadock BJ, Sadock VA, Ruiz P. Kaplan and Sadock's Synopsis of Psychiatry: Behavioral Sciences/ Clinical Psychiatry. 11th ed. Philadelphia, Pa: Wolters Kluwer; 2015. p. 697-704.

17. McCusker J, Cole MG, Dendukuri N, Belzile E. Does delirium increase hospital stay? J Am Geriatr Soc. 2003;51:1539-46. https://doi.org/10.1046/j.1532-5415.2003.51509.x

18. Kiely DK, Bergmann MA, Murphy KM, Jones RN, Orav EJ, Marcantonio ER. Delirium among newly admitted postacute facility patients: Prevalence, symptoms, and severity. J Gerontol A Biol Sci Med Sci. 2003;58:441-5. https://doi.org/10.1093/gerona/58.5.M441

19. Aslan M, Koroglu A, Helvacı Celik F, Hocaoglu C. An evaluation of cases with delirium in a training hospital. Düşünen Adam: The Journal of Psychiatry and Neurological Sciences. 2011;24(2):121-7. https://doi.org/10.5350/DAJPN2011240205

20. Kayaalp L, Odabası G, Dogangun B, Cavusoglu P, Bolat N, Bakan M, et al. Endoskopik izlem gerektiren korozif yanıkları olan çocuk ve ergenlerde kazanın meydana geliş şekli ve aile özelliklerinin değerlendirilmesi. Türk Pediatri Arşivi. 2006;41:24-30.

21. Karaçetin G, Demir T, Baghaki S, Çetinkale O, Elagöz Y. Psychiatric disorders and their association with burn-related factors in children with burn injury. Ulus Travma Acil Cerrahi Derg. 2014;20(3):176-80.

22. Yabanoğlu H, Yağmurdur MC, Taşkıntuna N, Karayalı H. Early period psychiatric disorders following burn trauma and the importance of surgical factors in the etiology. Ulus Travma Acil Cerrahi Derg. 2012;18(5):436-40. https://doi.org/10.5505/tjtes.2012.98511

23. Palmu R, Suominen K, Vuola J, Isometsa E. Psychiatric consultation and care after acute burn injury: A 6-month naturalistic prospective study. Gen Hosp Psychiatry. 2011;33:16-22. https://doi.org/10.1016/j.genhosppsych.2010.11.014

24. Edlich RF, Glasheen W, Attinger EO, Anne A, Haynes B, Hiebert JT. Epidemiology of serious burn injuries. Surg Gynecol Obstet. 1982;154:505-9.

25. Düzgün AP, Şenel $E$, Özmen MM, Kulaçoğlu $H$, Işık Y, Coşkun F. Evaluation of the patients admitted to a burn center in Turkey. Ulus Travma Derg. 2003;9:250-6.

26. Palmu R, Suominen K, Vuola J, Isometsa E. Mental disorders among acute burn patients. Burns. 2010;36:1072-9. https://doi.org/10.1016/j.burns.2010.04.004

27. Ter Smitten MH, de Graaf R, Van Loey NE. Prevalence and co-morbidity of psychiatric disorders 1-4 years after burn. Burns. 2011;37:753-61. https://doi.org/10.1016/j.burns.2010.12.018

28. Anlatıcı R, Özerdem ÖR, Dalay C, Kesiktaş E, Acartürk S, Seydaoğlu G. A retrospective analysis of 1083 Turkish patients with serious burns. Burns. 2002;28(3):239-43. https://doi.org/10.1016/S0305-4179(02)00030-X

29. Ilechukwu ST. Psychiatry of the medicaly ill in the burn unit. Psychiatr Clin North Am. 2002;25(1):129-47. https://doi.org/10.1016/S0193-953X(03)00055-8

30. Yuce Y, Kılavuz O. Profile of moderate and severe burns: Turkish experience in a tertiary care burn unit. The Ulutas Medical Journal. 2018;4(1):25-31. https://doi.org/10.5455/umj.20180221074628

31. Sıkar HE, Sıkar EY. Afyonkarahisar Devlet Hastanesi'nde yanık nedeniyle tedavi edilen hastaların değerlendirilmesi: Retrospektif çalışma. Kocaeli Med J. 2018;7(1):92-5. https://doi.org/10.5505/ktd.2018.68553

32. Özçetin B, Tihan D, Demirci H, Altıntaş MM, Arayıcı V, Taha A. Yeni kurulan bir yanık merkezinde 2.5 yıllık deneyim. Ulusal Cerrahi Dergisi. 2012;28(3):146-8. https://doi.org/10.5152/UCD.2012.04

33. Nursal TZ, Yıldırım S, Tarım A, Çalışkan K, Ezer A, Noyan T. Burns in Southern Turkey: Electrical burns remain a major problem. J Burn Care Rehabil. 2003;24(5):309-14. https://doi.org/10.1097/01.BCR.0000085876.28504.EE

34. Li F, Coombs D. Mental health history-a contributing factor for poorer outcomes in burn survivors. Burns \& Trauma. 2018;6(1):1-4. https://doi.org/10.4103/2321-3868.126080

35. Wisely JA, Wilson E, Duncan RT, Tarrier N. Pre-existing psychiatric disorders, psychological reactions to stress and the recovery of burn survivors. Burns. 2010;36:183-91. https://doi.org/10.1016/j.burns.2009.08.008

36. Van Loey NEE, Van Son MJM. Psychopathology and psychological problems in patients with burn scars: Epidemiology and management. Am J Clin Dermatol. 2003;4:245-72. https://doi.org/10.2165/00128071-200304040-00004

37. Pavan C, Grasso G, Costantini MV, Pavan L, Masier F, Azzi MF, et al. Accident proneness and impulsiveness in an Italian group of burn patients. Burns. 2009;35:247-55. https://doi.org/10.1016/j.burns.2008.07.002

38. Perez Jimenez JP, Gomez Bajo GJ, Lopez Castillo JJ, Salvador Robert M, Garcia Torres V. Psychiatric consultation and posttraumatic stres disorder among burned patients. Burns. 1994;20(6);532-6. https://doi.org/10.1016/0305-4179(94)90015-9

39. Mitchell AJ, Chan M, Bhatti H, Halton M, Grassi L, Johansen C, et al. Prevalence of depression, anxiety, and adjustment in oncological, haematological, and palliative-care settings: A meta-analysis of 94 interview-based studies. Lancet Oncol. 2011;12:160-74. https://doi.org/10.1016/S1470-2045(11)70002-X

40. Semprini F, Fava GA, Sonino N. The spectrum of adjustment disorders: Too broad to be clinically helpful. CNS Spectr. 2010;15:382-8 https://doi.org/10.1017/S1092852900029254

41. Kocalevent RD, Mierke A, Danzer G, Klapp BF. Adjustment disorders as a stress-related disorder: A longitudinal study of the associations among stres resources, and mental health. PLOS One. 2014;9(6):e101377. https://doi.org/10.1371/journal.pone.0101377

42. Mahendraraj K, Durgan DM, Chamberlain RS. Acute mental disorders and short and long term morbidity in patients with third degree flame burn: A population-based outcome study of 96.451 patients from nationwide inpatient sample (NIS) database (2001-2011). Burns. 2016;42(8):1766-73. https://doi.org/10.1016/j.burns.2016.06.001

43. Eser B, Batmaz S, Songur E, Yıldız M, Akpınar Aslan E. Bir üniversite hastanesinde yatan hastalar için ve acil servisten istenilen ruh sağlığı ve hastalıkları konsültasyonlarının incelenmesi: Türkiye'den çalışmalarla bir karşılaştırma. Klinik Psikiyatri. 2018;21:278-89.

44. Sertöz ÖÖ, Doğanavşargil GÖ, Noyan MA, et al. Bir üniversite hastanesi konsültasyon liyezon servisinde psikiyatrik hastalıkların psikiyatri dışı hekimlerce doğru tanınma oranları. Klinik Psikofarmakoloji Bülteni. 2008;18(4):288-95.

45. Ögel K. Madde kullanım bozuklukları epidemiyolojisi. Türkiye Klinikleri. 2005;1(47);61-4.

46. Clary GL, Krishnan KR. Delirium: Diagnosis, neuropathogenesis and treatment. J Psychiatr Pract. 2001;7(5):310-23. https://doi.org/10.1097/00131746-200109000-00004

47. Meagher DJ. Delirium: Optimising management. BMJ. 2001;322:145-9. https://doi.org/10.1136/bmj.322.7279.144

48. Kırpınar I. Deliryum: Tanı, oluş nedenleri, bakım ve tedavi yaklaşımları. Türkiye Klinikleri Psikiyatri Özel Dergisi. 2009;2:113. 
49. Kahyacı Kılıç E, Köse Çınar R, Sönmez MB, Görgülü Y. Bir üniversite hastanesinde yatan hastalardan istenen psikiyatrik konsultasyonların değerlendirilmesi. Klinik Psikiyatri. 2016;19:194-201. https://doi.org/10.5505/kpd.2016.07108

50. Göktaş K, Yılmaz E, Kaya N, et al. Bir eğitim hastanesinde istenen psikiyatri konsültasyonlarının değerlendirilmesi. Anadolu Psikiyatri Dergisi. 2006;7(1):27-32.

51. Köroğlu A, Çelik FH, Aslan $M$, et al. Bir eğitim hastanesinde psikiyatri konsültasyon hizmetlerinin değerlendirilmesi. Klinik Psikiyatri. 2011;14:44-50.

52. McKibben JB, Bresnick MG, Wiechman Askay SA, Fauerbach JA. Acute stress disorder and posttraumatic stress disorder: A prospective study of prevalence, course, and predictors in a sample with major burn injuries. I Burn Care Res. 2008;29(1):22-35.

https://doi.org/10.1097/BCR.0b013e31815f59c4 